\section{The Potential Contribution of Phytoestrogens and Organochlorine Pesticides in an Experimental Fish Diet to Estrogenic Activity}

\author{
Munekazu Matsuoka, ${ }^{a}$ Hiroshi Ishibashi, ${ }^{a}$ \\ Marie Ushijima, ${ }^{b}$ Makiko Inudo, ${ }^{a}$ \\ Eiko Honda, ${ }^{a}$ Masayoshi Iwahara, ${ }^{b}$ \\ Hyeon-Seo Cho, ${ }^{c}$ Yasuhiro Ishibashi, ${ }^{d}$ \\ and Koji Arizono*,a
}

${ }^{a}$ Faculty of Environmental and Symbiotic Sciences, Prefectural University of Kumamoto, 3-1-100 Tsukide, Kumamoto 8628502, Japan, ${ }^{b}$ Faculty of Engineering, Sojo University, 4-221 Ikeda, Kumamoto 860-0082, Japan, 'Yosu National University, Division of Ocean System, San 96-1 Dunduck-dong, Yeosusi, Leollanam-do 550-749, Korea, and ${ }^{d}$ Environmental Protection Center, Nagasaki University, 1-14 Bunkyo, Nagasaki 8528521, Japan

(Received November 11, 2004; Accepted January 12, 2005; Published online January 17, 2005)

Phytoestrogens and organochlorine pesticides in the diet of laboratory animals are a possible source of interference in bioassays that assess estrogenic activity. In the present study, we investigated the levels of dietary phytoestrogens, organochlorine pesticides and the estrogenic activity of various diets for an experimental fish and discuss the potential contribution of these substances to estrogenic activity, in comparison with those used in previous studies. After hydrolysis with $\beta$-glucuronidase, genistein and daidzein were detected in all of the diets, and there were no significant differences in the contents of these substances among present and previous investigations. In addition, organochlorine pesticides, such as hexachlorobenzene (HCB), $\beta$-benzene hexachloride ( $\beta$-BHC), $\gamma$-BHC, trans-nonachlor, and/or endrin, were detected in most fish diets. All of these diets exhibited higher levels of activation of $\beta$ estrogen receptors than with $\alpha$ estrogen receptors in an in vitro yeast-based bioassay. These results indicate that phytoestrogens, such as genistein and daidzein, were the main substances contributing to the estrogenic activity of the diet. Moreover, some

\footnotetext{
*To whom correspondence should be addressed: Faculty of Environmental and Symbiotic Sciences, Prefectural University of Kumamoto, 3-1-100 Tsukide, Kumamoto 862-8502, Japan. Tel.: +81-96-383-2929 (ext. 486); Fax: +81-96-383-6062; E-mail: arizono@pu-kumamoto.ac.jp
}

diets may exert estrogenic activity in in vivo tests, indicating the necessity for more careful selection of the feeding diet and measurement of estrogenic substances when performing routine screening assays for endocrine-disrupting chemicals.

Key words — endocrine-disrupting chemical, phytoestrogen, organochlorine pesticide, estrogenic activity, fish diet

\section{INTRODUCTION}

The public and scientific concerns of endocrinedisrupting chemicals (EDCs) present in the human diet and in the environment, and their potency to disrupt the normal hormonal status in humans and wildlife, have become a high-profile international issue. ${ }^{1-3)}$ Many of these EDCs have similar structures to natural and synthetic hormones, and can accidentally bind to steroid hormone receptors, such as estrogen, androgen and thyroid receptors. In order to regulate and minimize the release of hormonally active agents into the environment, the Organization for Economic Cooperation and Development (OECD) initiated a high-priority activity in 1997 to develop new and revised guidelines for screening and testing potential EDCs. ${ }^{4}$ For the screening of estrogenic substances, many in vitro and in vivo assays were developed and conducted: MCF-7 cell proliferation assay (E-screen assay), ${ }^{5)}$ yeast estrogen-screen assay (YES assay), ${ }^{6}$ yeast two-hybrid assay, ${ }^{7,8)}$ rat uterotrophic assay ${ }^{9}$ and the vitellogenin ( $\mathrm{Vg}$, egg yolk protein precursor) production assay. ${ }^{10,11)}$ Since the estrogenic effect of test chemicals on individual animals is examined with in vivo assays, fish are often used as a laboratory test animal and also as representatives of aquatic animals. During these in vivo assays, fish are often fed on commercial diets.

Phytoestrogens in the laboratory diet are a possible source of interference with bioassays that assess estrogenic activity. Phytoestrogens and derivatives, such as genistein, daidzein, coumestrol and equol, could potentially disturb the reproductive function in mammals. ${ }^{12,13)}$ Many of these compounds may act as estrogen receptor agonists, binding to estrogen receptors and stimulating estrogen-responsive gene expression, ${ }^{14,15)}$ or may antagonize the binding of endogenous estrogen to its receptors and exert anti-estrogenic physiological effects. ${ }^{16)}$ For 
example, phytoestrogens have been shown to elicit statistically significant increases in uterine weights at high doses in the uterotrophic assay. ${ }^{17)}$ Our previous study also demonstrated the effects of a phytoestrogen-enriched diet on the production of plasma Vg and steroid hormones in male goldfish (Carassius auratus). ${ }^{18)}$ Phytoestrogens such as coumestrol and equol exhibit higher binding affinities for the estrogen receptor than those of known xenoestrogens such as bisphenol A and nonylphenol. ${ }^{19)}$

Persistent organic pollutants, some with known potential as EDCs, are adventitial compounds present in a variety of diets. ${ }^{20)}$ To date, many of these chemicals, such as $\beta$-benzene hexachloride ( $\beta$-BHC), $p, p^{\prime}$ dichlorodiphenyl dichloroethylene (DDE), $o, p^{\prime}$ dichlorodiphenyl trichloroethane (DDT) and endrin, have been reported as estrogenic pesticides. ${ }^{21)}$ The studies have also revealed anti-androgenic pesticides, such as vinclozolin and $p, p^{\prime}$-DDE. ${ }^{21)}$ Our previous study demonstrated that organochlorine pesticides, such as hexachlorobenzene (HCB), $\beta$-BHC, and/or $\gamma-\mathrm{BHC}$, could be detected in fish diets. ${ }^{22)} \mathrm{Al}-$ though there are a few studies concerning adventitious contaminants, such as phytoestrogens and organochlorine pesticides, ${ }^{22,23)}$ the potential contribution of these chemicals in unpurified commercial fish diets is unknown. It is possible that estrogenic substances in the fish diet compete with test chemicals in binding estrogen receptors in the in vivo estrogen assay and may affect the estimation of the estrogenic activity of test chemicals.

In the present study, we assessed the levels of dietary phytoestrogens, organochlorine pesticides and the estrogenic activity of various diets for an experimental fish and discuss the potential contribution of these substances to estrogenic activity compared with diets tested in previous studies.

\section{MATERIALS AND METHODS}

Measurement of Genistein and Daidzein — Six diets for teleost fish (such as mullet and sea bream) used in the present study, are commercial available in Korea, respectively. The extraction of phytoestroges (genistein and daidzein) and estrogenic substances from fish diets was performed by previous methods as described by Miyahara et al. ${ }^{23)}$ Briefly, five grams of crushed sample was homogenized with $40 \mathrm{ml}$ of methanol and $1 \mathrm{M}$-acetic acid buffer solution (9:1 volume ratio, $\mathrm{pH} 4.5)$. After homogenization, the sample was sonicated for $10 \mathrm{~min}$ in a $50 \mathrm{ml}$ centrifuge tube. After shaking by hand for $10 \mathrm{~min}$, the tube was centrifuged at $2000 \mathrm{rpm}$ for $10 \mathrm{~min}$. The supernatant was transferred to a $200 \mathrm{ml}$-measuring flask. A fresh batch of the methanol-acetic acid buffer solution was added to the precipitate that remained in the centrifuge tube and the operation was repeated. Then the extract was adjusted to $200 \mathrm{ml}$ with methanol. A portion (1 or $2 \mathrm{ml}$ ) of the extract was dried under nitrogen at room temperature. In the case of enzymatic hydrolysis, the dried extract was redissolved in $200 \mu$ l of purified water by vortex mixing. This solution was mixed with $1 \mathrm{ml}$ of $0.5 \mathrm{M}$ acetic acid buffer solution $(\mathrm{pH} 4.5)$ containing $2100 \mathrm{U} \beta$-glucuronidase and $1050 \mathrm{U}$ arylsulfatase (Nippon Biotest Laboratories Inc., Tokyo, Japan). The reaction mixture was incubated overnight at $37^{\circ} \mathrm{C}$. After the incubation, phytoestrogens and/or estrogenic substances present in the sample was extracted twice with $5 \mathrm{ml}$ diethyl ether followed by drying under nitrogen at room temperature. In the sample both with and without hydrolysis, the dried extract was redissolved in $200 \mu \mathrm{l}$ methanol-acetonitrile-purified water mixture $(2: 1: 3$ volume ratio) for measurement of genistein and daidzein, and 100\% dimethylsulfoxide (DMSO, Wako Pure Chemical Industries, Ltd., Tokyo, Japan) for measurement of estrogenic activity.

The measurement of genistein and daidzein were determined by a high-performance liquid chromatography (HPLC) as described by Miyahara et al. ${ }^{23)}$ Five milligrams of genistein (Wako Pure Chemical Industries Ltd.) and daidzein (Fijicco Co. Ltd., Tokyo, Japan) were each dissolved in $10 \mathrm{ml}$ of methanol and diluted to a concentration of $100 \mu \mathrm{g} / \mathrm{ml}$ to prepare standard solutions. Each standard solution was diluted sequentially to prepare solutions with concentrations of $0.1,0.2,0.5,1.0,2.5,5.0$ and $10 \mu \mathrm{g} / \mathrm{ml}$. To prepare the samples for measurement, the sample was sonicated for $1 \mathrm{~min}$. After centrifugation for $1 \mathrm{~min}$ at $10000 \mathrm{rpm}$ using Ultrafree-MC ( $0.22 \mu \mathrm{m}$, Millipore, Tokyo, Japan), $20 \mu \mathrm{l}$ of the elute was injected into the HPLC system, which was an LC 2000 Plus series HPLC manufactured by JASCO with a PEGASIL ODS analysis column $(4.6 \times$ 150 mm; manufactured by Senshu Kagaku, Tokyo, Japan). The mobile phases used were a mixture of methanol and acetonitrile $(2: 1)$ and $0.1 \%$ acetic acid employing a linear gradient with ultraviolet detection at $280 \mathrm{~nm}$. The eluted peak was measured on the basis of the obtained peak area. In this assay, the minimum detection limit was $0.5 \mu \mathrm{g} / \mathrm{ml}$ for genistein 
and daidzein. In this system, the recovery of both substances from the fish diet was more than $90 \%$. The coefficient of variation for the inter-assay was $2 \%$ or less $(n=3)$, and the coefficient of variation for the intra-assay was $5 \%$ or less $(n=3) .{ }^{23)}$

\section{Measurement of Organochlorine Pesticides}

The measurement of organochlorine pesticides was performed by previous methods as described by Inudo et al. ${ }^{22)}$ Briefly, three hundreds milligrams of crushed sample was extracted with $5 \mathrm{ml}$ of $n$-hexane by mild sonication for $10 \mathrm{~min}$, and centrifuged at $2000 \mathrm{rpm}$ for $10 \mathrm{~min}$. The supernatant was transferred into a $10 \mathrm{ml}$ tube. On the residue, the above operations were repeated once. The supernatants thus obtained were combined and treated with a Sep-Pak Florisil cartridge column (500 mg, Waters, U.S.A.). The eluant was added to $1 \mathrm{ml}$ of dodecane and $200 \mu \mathrm{l}$ of 1-nitropyren $(1 \mathrm{mg} / \mathrm{l})$ internal standard solution, concentrated to $1 \mathrm{ml}$ with a Syncore Polyvap R-24, and then analyzed for the organochlorine pesticides profiles by a gas chromatography (GC) with electron capture detection (ECD), as described below.

A GC/ECD was performed on a Agilent 6890 GC system (Agilent Technologies, U.S.A.) using a Hewlett-Packard HP-5 capillary column $(30 \mathrm{~m} \times$ $0.32 \mathrm{~mm}, 0.25 \mu \mathrm{m}$ film thickness). The temperature program was as follow: $50^{\circ} \mathrm{C}$ for $1.5 \mathrm{~min}, 30^{\circ} \mathrm{C} / \mathrm{min}$ to $200^{\circ} \mathrm{C}$, held for $3 \mathrm{~min}, 20^{\circ} \mathrm{C} / \mathrm{min}$ to $260^{\circ} \mathrm{C}$, and $4^{\circ} \mathrm{C} / \mathrm{min}$ to $280^{\circ} \mathrm{C}$, held for $2 \mathrm{~min}$. Injector and detector temperatures were at 200 and $300^{\circ} \mathrm{C}$, respectively. Helium was used as carrier gas at $47 \mathrm{~cm} / \mathrm{sec}$. Injection volume was $2 \mu \mathrm{l}$. The following organochlorine pesticides were screened for and routinely detected in the sample: $\mathrm{HCB}, \beta$-BHC, $\gamma$-BHC, vinclozolin, $p, p^{\prime}$-DDE, trans-nonachlor ( $t$-nonachlor), endrin and $o, p^{\prime}$-DDT.

Measurement of Estrogenic Activity — The estrogenic activities of fish diets were measured by a yeast two-hybrid assay as described by Miyahara et $a{ }^{23)}$ and Shiraishi et $a l .{ }^{8)}$ This system was performed with yeast cells (Saccharomyces cervisiae Y190) prepared by incorporating the human estrogen receptor $\alpha(\mathrm{ER} \alpha)$ and $\beta(\mathrm{ER} \beta)$, an expression plasmid of the coactivator transcription intermediary factor 2 (TIF2), and a $\beta$-galactosidase expression reporter in the yeast two-hybrid system. ${ }^{7)}$

Aliquots of sample solutions $(20 \mu \mathrm{l})$ were incubated $\left(30^{\circ} \mathrm{C}, 4 \mathrm{hr}\right)$ with yeast cells in a $96-w e l l$ microplate (SUMILON, Sumitomo Bakelite, Japan) that had been preincubated $\left(30^{\circ} \mathrm{C}\right.$, overnight $)$ in modified synthetic dropout medium lacking tryptophan and leucine. A mix solution for inducing chemiluminesence and for enzymatic digestion (Zymolyase 20T, Seikagaku, Corp., Tokyo, Japan) was added followed by a light emission accelerator solution. The chemiluminesence produced by released $\beta$-galactosidase was measured with a 96-well plate luminometer (Luminescencer-JNR AB2100, ATTO Bio-Instrument, Tokyo, Japan). Estrogenic activity was recorded as the $\mathrm{EC}_{\times 10}$ which was defined as the concentration (weight base) of test solution producing a chemiluminescent signal $10 \times$ that of the blank control. As the inverse of the obtained $\mathrm{EC}_{\times 10}$ values of estradiol-17 $\beta$ (E2, Sigma, St. Louis, MO, U.S.A.), similar procedures were taken for other samples to calculate the E2 equivalent.

In addition, we evaluated the estrogenic activity level of the feeding diet for experimental fish found by the yeast two-hybrid assay and the total content of genistein and daidzein analysed by HPLC to study the relationship between estrogenic activity and the phytoestrogen content. ${ }^{23)} \mathrm{We}$ used the $\mathrm{EC}_{\times 10}$ values of E2, found by the yeast two-hybrid assay for genistein and daidzein to calculate the E2 conversion of total genistein and total daidzein contents in the diet as measured by HPLC, respectively. We used the sum of these values as the E2 conversion of the phytoestrogen (genistein and daidzein) content. On the other hand, by using the $\mathrm{EC}_{\times 10}$ values of $\mathrm{E} 2$, genistein and daidzein found by the yeast two-hybrid method and the $\mathrm{EC}_{\times 10}$ value of different types of diet, we calculated the estrogenic activity E2 conversion by the yeast two-hybrid assay.

\section{RESULTS}

\section{Phytoestrogen Levels}

In order to assess the genistein and daidzein content in the fish diet from Korea, genistin and daidzin present as glycosides were hydrolyzed with $\beta$-glucuronidase and sulfatase. The total amounts of genistein and daidzein in the fish diet tested in this study are shown in Table 1. The No. 3 diet contained the largest amount of genistein at $118.9 \pm 1.2 \mu \mathrm{g} / \mathrm{g}$, followed by the No. 2 diet $(115.7 \pm 2.0 \mu \mathrm{g} / \mathrm{g})$, No. 1 $\operatorname{diet}(79.9 \pm 3.7 \mu \mathrm{g} / \mathrm{g})$, No. $5 \operatorname{diet}(59.2 \pm 1.9 \mu \mathrm{g} / \mathrm{g})$, No. $6 \operatorname{diet}(58.2 \pm 0.5 \mu \mathrm{g} / \mathrm{g})$ and No. $4 \operatorname{diet}(39.7 \pm$ $0.5 \mu \mathrm{g} / \mathrm{g})$. Similarly, No. 3 diet contained the largest total amount of daidzein $(81.3 \pm 0.8 \mu \mathrm{g} / \mathrm{g})$, followed by the No. $2 \operatorname{diet}(78.4 \pm 1.1 \mu \mathrm{g} / \mathrm{g})$, No. $1 \operatorname{diet}(60.0$ $\pm 2.1 \mu \mathrm{g} / \mathrm{g})$, No. $6 \operatorname{diet}(42.1 \pm 0.8 \mu \mathrm{g} / \mathrm{g})$, No. 5 diet $(40.1 \pm 0.9 \mu \mathrm{g} / \mathrm{g})$ and No. $4 \operatorname{diet}(28.7 \pm 0.3 \mu \mathrm{g} / \mathrm{g})$. From a comparison of phytoestrogen levels in fish 
diets from present and previous investigations, ${ }^{22,23)}$ there were no significant differences in the genistein or daidzein contents $(p>0.05$, Fisher'PLSD Posthoc test) (Fig. 1).

\section{Organochlorine Pesticide Levels}

The organochlorine pesticide profiles in the fish diet samples are shown in Table 2. HCB, $\beta$-BHC and $\gamma$-BHC showed the highest concentrations in the No. 6 diet $(13.33,23.53$ and $24.97 \mathrm{ng} / \mathrm{g}$, respectively). The concentrations of $\mathrm{HCB}, \beta-\mathrm{BHC}$ and $\gamma-$ BHC in the No. $5 \operatorname{diet}(8.15,14.18$ and $10.13 \mathrm{ng} / \mathrm{g}$, respectively) were lower than those of the No. 6 diet. In addition, No. 5 diet was found to contain endrin $(28.15 \mathrm{ng} / \mathrm{g})$. HCB, $\gamma$-BHC and $t$-nonachlor were detected in the No. 2 diet (5.11, 8.3 and $14.28 \mathrm{ng} / \mathrm{g}$, respectively) and the No. 1 and 4 diets were found to contain only $t$-nonachlor and HCB, respectively ( 8.41 and $1.62 \mathrm{ng} / \mathrm{g}$, respectively). In the No. 3 diet, no organochlorine pesticides were detected.

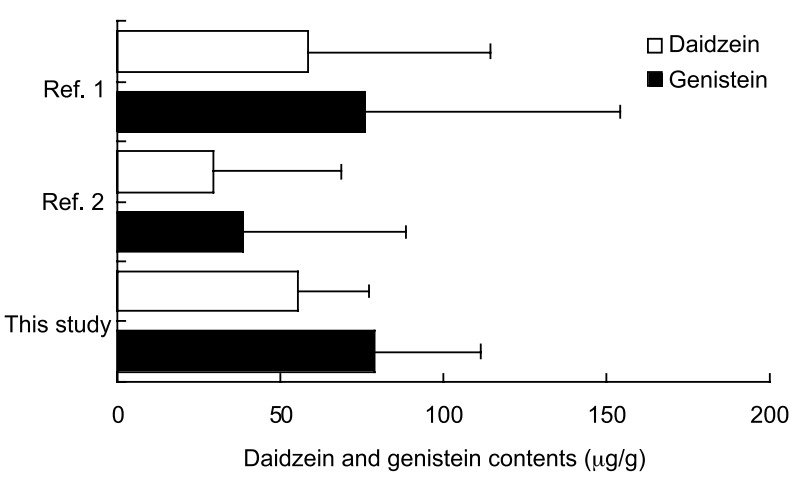

Fig. 1. Comparison of Phytoestrogen Levels in Fish Diets from Present and Previous Investigations

Data represented are the means and standard deviation. Ref. 1: Miyahara et al., $2003(n=8)$; Ref. 2: Inudo et al., $2004(n=6)$.

\section{Estrogenic Activity for ER $\alpha$ and ER $\beta$}

We evaluated the estrogenic activity of the fish diet for $\mathrm{ER} \alpha$ and $\mathrm{ER} \beta$ using the yeast two-hybrid assay. No estrogenic activity was detected by the yeast two-hybrid assay for $\mathrm{ER} \alpha$ and $\mathrm{ER} \beta$ without prior hydrolysis of the diets (data not shown). However, after hydrolysis by $\beta$-glucuronidase, the No. 2 and/or No. 3 diets showed the highest estrogenic activity for $\mathrm{ER} \alpha$ and $\mathrm{ER} \beta$. The $\mathrm{EC}_{\times 10}$ values of the No. 2 diet for $\operatorname{ER} \alpha$ and $\operatorname{ER} \beta$ were estimated to be $338.2 \pm 46.8$ and $75.2 \pm 9.3 \mu \mathrm{g} / \mathrm{ml}$, respectively, and the E2 equivalents were noted as $84.2 \pm 3.6$ and 489.0 $\pm 16.6 \mathrm{ng} / \mathrm{g}$, respectively (Table 1 ). Similarly, the $\mathrm{EC}_{\times 10}$ values of the No. 3 diet for $\mathrm{ER} \alpha$ and $\mathrm{ER} \beta$ were estimated to be $354.7 \pm 1.6$ and $70.1 \pm 9.6 \mu \mathrm{g} / \mathrm{ml}$, respectively, and the E2 equivalents were noted at $72.8 \pm 4.5$ and $525.0 \pm 8.1 \mathrm{ng} / \mathrm{g}$, respectively (Table 1). The $\mathrm{EC}_{\times 10}$ values of the No. 4 diet for $\mathrm{ER} \beta$ were estimated to be $253.8 \pm 49.7 \mu \mathrm{g} / \mathrm{ml}$, and the E2 equivalent concentration was noted as $150.7 \pm$ $8.5 \mathrm{ng} / \mathrm{g}$ (Table 1). The E2 equivalents of No. 1, 5 and 6 diets for $\mathrm{ER} \alpha$ were estimated to be $54.0 \pm 3.1$, $73.8 \pm 3.5$ and $27.7 \pm 1.6 \mathrm{ng} / \mathrm{g}$, respectively, and the E2 equivalents of these diets for ER $\beta$ were calculated as $421.2 \pm 26.3,494.0 \pm 13.2$ and $272.6 \pm$ $6.1 \mathrm{ng} / \mathrm{g}$, respectively (Table 1 ). However, in the No. 4 diet, the values of $\mathrm{EC}_{\times 10}$ and $\mathrm{E} 2$ equivalents could not determined as a result of the low estrogenic activity for ER $\alpha$. All of the diets exhibited higher levels of activation of $\operatorname{ER} \beta$ than with $\operatorname{ER} \alpha$ (Fig. 2).

\section{Relationship between Estrogenic Activity and Phytoestrogens in the Fish Diet}

In most diets (for $\mathrm{ER} \alpha$ and $\mathrm{ER} \beta$ ), a positive correlation was found between the E2 conversion from the phytoestrogen content and the estrogenic activity of E2 conversion by the yeast two-hybrid assay

Table 1. Levels of Phytoestrogens (Genistein and Daidzein) and Estrogenic Activities for ER $\alpha$ and ER $\beta$ in Fish Diets

\begin{tabular}{|c|c|c|c|c|c|c|}
\hline \multirow[t]{3}{*}{ Diet No. } & \multicolumn{2}{|c|}{ 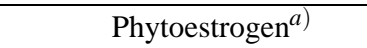 } & \multicolumn{4}{|c|}{ 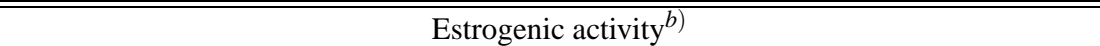 } \\
\hline & \multirow{2}{*}{$\begin{array}{c}\text { Genistein } \\
(\mu \mathrm{g} / \mathrm{g})\end{array}$} & \multirow{2}{*}{$\begin{array}{c}\text { Daidzein } \\
(\mu \mathrm{g} / \mathrm{g})\end{array}$} & \multicolumn{2}{|c|}{$\mathrm{ER} \alpha$} & \multicolumn{2}{|c|}{$\mathrm{ER} \beta$} \\
\hline & & & $\mathrm{EC}_{\times 10}(\mu \mathrm{g} / \mathrm{ml})$ & E2 equivalent (ng/g) & $\mathrm{EC}_{\times 10}(\mu \mathrm{g} / \mathrm{ml})$ & E2 equivalent (ng/g) \\
\hline 1 & $79.9 \pm 3.7$ & $60.0 \pm 2.1$ & $445.2 \pm 48.5$ & $54.0 \pm 3.1$ & $92.6 \pm 25.4$ & $421.2 \pm 26.3$ \\
\hline 2 & $115.7 \pm 2.0$ & $78.4 \pm 1.1$ & $338.2 \pm 46.8$ & $84.2 \pm 3.6$ & $75.2 \pm 9.3$ & $489.0 \pm 16.6$ \\
\hline 3 & $118.9 \pm 1.2$ & $81.3 \pm 0.8$ & $354.7 \pm 1.6$ & $72.8 \pm 4.5$ & $70.1 \pm 9.6$ & $525.0 \pm 8.1$ \\
\hline 4 & $39.7 \pm 0.5$ & $28.7 \pm 0.3$ & $>2500^{c)}$ & $<11.0^{c)}$ & $253.8 \pm 49.7$ & $150.7 \pm 8.5$ \\
\hline 5 & $59.2 \pm 1.9$ & $40.1 \pm 0.9$ & $354.7 \pm 18.5$ & $73.8 \pm 3.5$ & $70.8 \pm 6.5$ & $494.0 \pm 13.2$ \\
\hline 6 & $58.2 \pm 0.5$ & $42.1 \pm 0.8$ & $938.1 \pm 85.0$ & $27.7 \pm 1.6$ & $128.1 \pm 8.2$ & $272.6 \pm 6.1$ \\
\hline
\end{tabular}

a) Data of phytoestrogen content represent the mean and standard deviation $(n=3) . b$ ) Data of estrogenic activity for $\operatorname{ER} \alpha$ and $\operatorname{ER} \beta$ represent the mean and standard deviation $(n=3) . c$ ) Not detectable in the tested concentration range (39-2500 $\mu \mathrm{g}$ fish diet $/ \mathrm{ml})$. 
$(p<0.001$, Fig. 3).

\section{DISCUSSION}

Phytoestrogens and organochlorine pesticides in the diet used for laboratory test animals are a possible source of interference with bioassays that assess estrogenic activity. In the present study, we as-
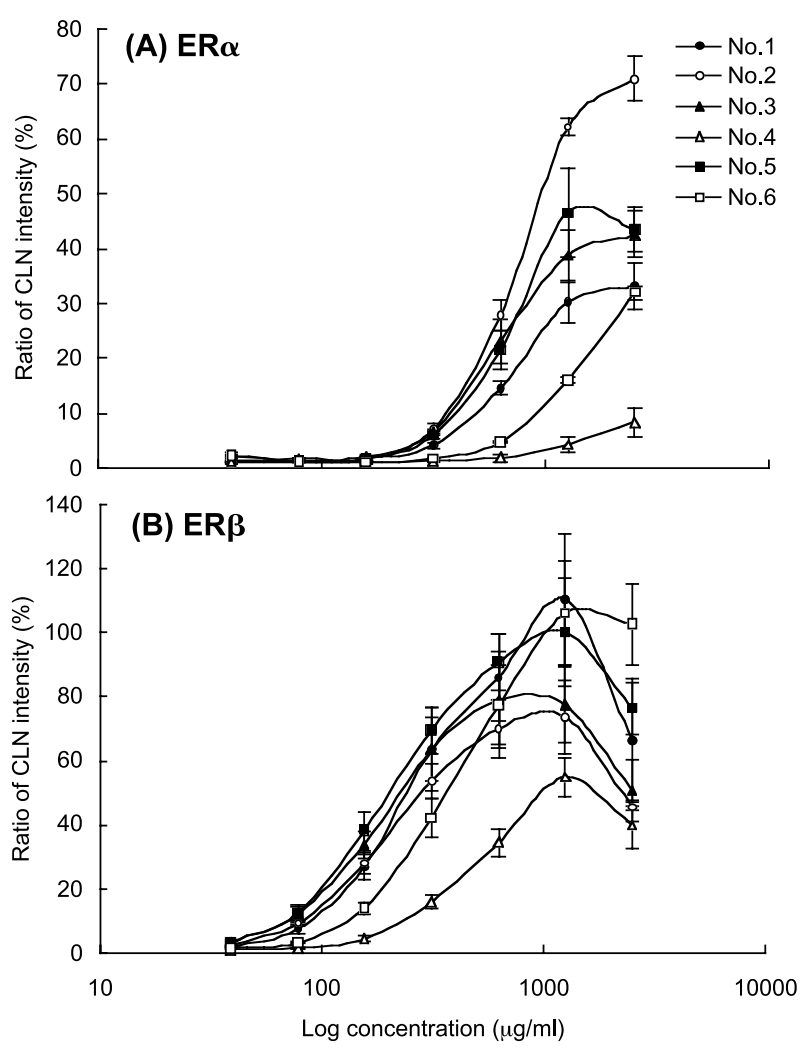

Fig. 2. Dose-Response Curves for Fish Diets after Hydrolysis Using the Agonist Test for the Yeast Two-Hybrid Assay for $\operatorname{ER} \alpha(\mathrm{A})$ and $\operatorname{ER} \beta(\mathrm{B})$

The values are calculated as a ratio of the chemiluminescence (CLN) intensity $(\mathrm{T} / \mathrm{B})$ of $\beta$-galactosidase. Data represented are the means and standard deviation $(n=3)$. sessed the levels of dietary phytoestrogens, organochlorine pesticides and the estrogenic activity of various diets for an experimental fish and discuss the potential contribution of these substances to estrogenic activity in comparison with those tested in previous studies.

Genistein (concentrations ranging from 39.7 to $118.9 \mu \mathrm{g} / \mathrm{g}$ ) and daidzein (concentrations ranging from 28.7 to $81.3 \mu \mathrm{g} / \mathrm{g}$ ) were detected in all fish diets tested in this study. These concentrations of phytoestrogens are consistent with our previous studies, and there were no differences between the regions tested in this study, namely Japan, ${ }^{23)}$ the United Kingdom $^{22)}$ and Korea. Court and Freeman measured the genistein and daidzein content in different types of commercial cat food, and reported that genistein and daidzein were detected in 24 out of 42 types that were surveyed, within a concentration range of 1 to $163 \mu \mathrm{g} / \mathrm{g} .{ }^{24)}$ In this study, the No. 3 diet was found to contain the highest levels of genistein (118.9 $\pm 1.2 \mu \mathrm{g} / \mathrm{g})$ and daidzein $(81.3 \pm 0.8 \mu \mathrm{g} / \mathrm{g})$, but showed lower levels of genistein and daidzein than those found in commercial cat food. These results indicate that most types of commercial fish diet contain phytoestrogens, such as genistein and daidzein, as well as in the commercial cat food reported in a previous study.

In soybean, the following 12 isoflavone types have been identified: 3 types of aglycon (daidzein, genistein and glycitein), their glycosides (daidzin, genistin and glycitin), and their malonylized glycosides and acetylized glycosides. ${ }^{25)}$ Among these isoflavones, the estrogenic activities of genistein and daidzein are reported to be higher than those of genistin and daidzin. ${ }^{23)}$ In this study, we hydrolyzed the genistin and daidzin glycosides in the diet in order to measure the total amount of genistein and daidzein. The amount of glycosides without hydrolysis and the content of genistin and daidzin are unknown. However, no estrogenic activities were de-

Table 2. Contents of Organochlorine Pesticides in Fish Diets using GC/ECD Analysis

\begin{tabular}{|c|c|c|c|c|c|c|c|c|}
\hline Diet No. & $\begin{array}{l}\text { HCB } \\
(\mathrm{ng} / \mathrm{g})\end{array}$ & $\begin{array}{c}\beta-\mathrm{BHC} \\
(\mathrm{ng} / \mathrm{g})\end{array}$ & $\begin{array}{c}\gamma-\mathrm{BHC} \\
(\mathrm{ng} / \mathrm{g})\end{array}$ & $\begin{array}{c}\text { Vinclozolin } \\
\text { (ng/g) }\end{array}$ & $\begin{array}{c}p, p^{\prime}-\mathrm{DDE} \\
(\mathrm{ng} / \mathrm{g})\end{array}$ & $\begin{array}{c}t \text {-nonachlor } \\
(\mathrm{ng} / \mathrm{g})\end{array}$ & $\begin{array}{c}\text { Endrin } \\
\text { (ng/g) }\end{array}$ & $\begin{array}{c}o, p^{\prime}-\mathrm{DDT} \\
(\mathrm{ng} / \mathrm{g})\end{array}$ \\
\hline 1 & N.D. ${ }^{a)}$ & N.D. ${ }^{b)}$ & N.D. ${ }^{c)}$ & N.D. ${ }^{d)}$ & N.D. ${ }^{d)}$ & 8.41 & N.D.f) & N.D. $\left.{ }^{g}\right)$ \\
\hline 2 & 5.11 & N.D. ${ }^{b)}$ & 8.3 & N.D. $\left.{ }^{d}\right)$ & N.D. ${ }^{d)}$ & 14.28 & N.D..$\left.^{f}\right)$ & N.D. $\left.{ }^{g}\right)$ \\
\hline 3 & N.D. ${ }^{a)}$ & N.D. ${ }^{b)}$ & N.D. ${ }^{c)}$ & N.D. ${ }^{d)}$ & N.D. ${ }^{d)}$ & N.D. ${ }^{e)}$ & N.D. $f)$ & N.D. $\left.{ }^{g}\right)$ \\
\hline 4 & 1.62 & N.D. ${ }^{b)}$ & N.D. ${ }^{c)}$ & N.D. ${ }^{d)}$ & N.D. ${ }^{d)}$ & N.D. ${ }^{e)}$ & N.D. $\left.f^{f}\right)$ & N.D. $\left.{ }^{g}\right)$ \\
\hline 5 & 8.15 & 14.18 & 10.13 & N.D. ${ }^{d)}$ & N.D. ${ }^{d)}$ & N.D. ${ }^{e)}$ & 28.15 & N.D. $\left.{ }^{g}\right)$ \\
\hline 6 & 13.33 & 23.53 & 24.97 & N.D. ${ }^{d)}$ & N.D. ${ }^{d)}$ & N.D. ${ }^{e)}$ & N.D. $f)$ & N.D. $\left.{ }^{g}\right)$ \\
\hline
\end{tabular}

N.D.: Quantity limit. $a)<0.05 \mathrm{ng} / \mathrm{g} ; b)<0.13 \mathrm{ng} / \mathrm{g} ; c)<0.1 \mathrm{ng} / \mathrm{g} ; d)<1.67 \mathrm{ng} / \mathrm{g} ; e)<0.5 \mathrm{ng} / \mathrm{g} ; f) 1.0 \mathrm{ng} / \mathrm{g} ; g) 0.83 \mathrm{ng} / \mathrm{g}$. 

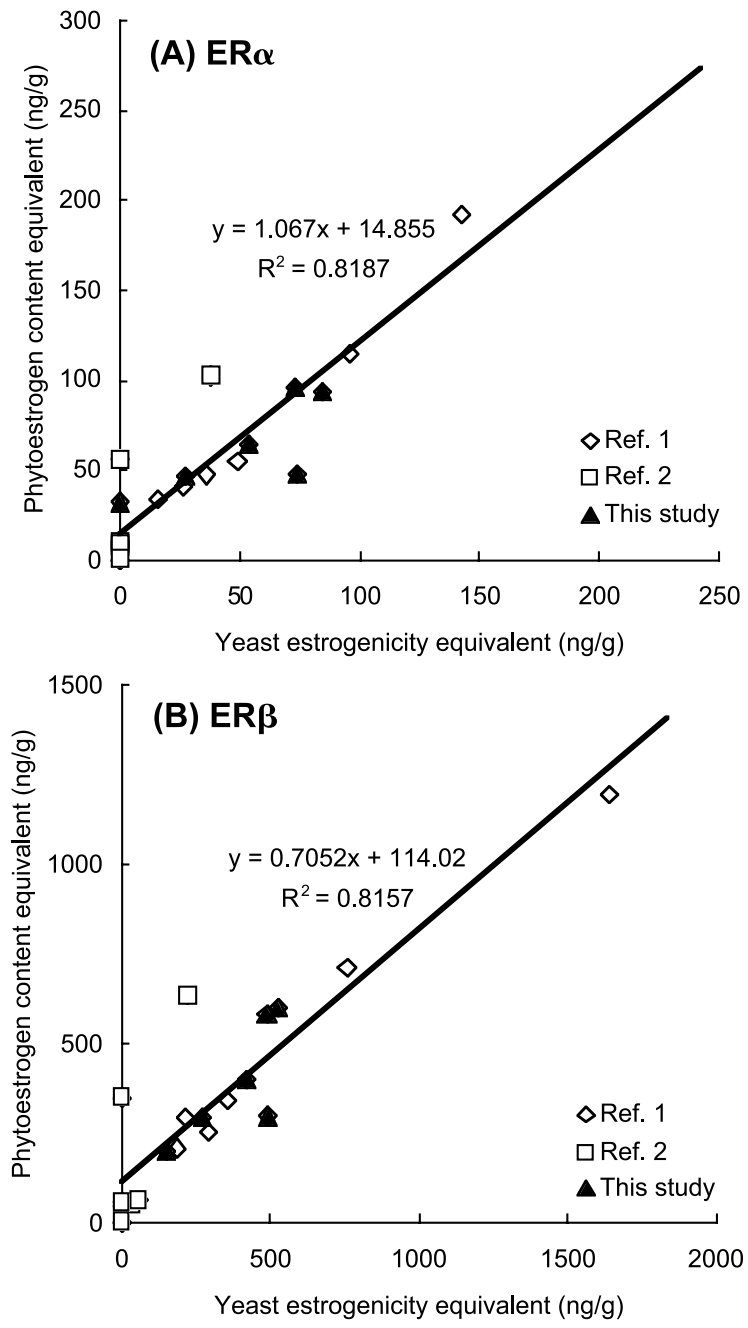

Fig. 3. Relatonship between the Estrogenicity Equivalents from the Estrogenic Activities for $\operatorname{ER} \alpha(\mathrm{A})$ and $\mathrm{ER} \beta(\mathrm{B})$ Using the Yeast Two-Hybrid Assay and the Estrogenicity Equivalents from Genistein and Daidzein Contents after HPLC Analysis of an Experimental Animal Diet

Ref. 1: Miyahara et al., $2003(n=8)$; Ref. 2: Inudo et al., 2004 $(n=6)$.

tected in the yeast two-hybrid assay for $\mathrm{ER} \alpha$ and $\mathrm{ER} \beta$ without hydrolysis, although estrogenic activity was detected after hydrolysis. It is possible that these phytoestrogens were present in the form of genistin and daidzin, which were hydrolyzed and then detected as genistein and daidzein. Furthermore, all diets that had estrogenic activity showed higher affinity for the $\beta$ receptor than for the $\alpha$ receptor. Kuiper et al. ${ }^{26)}$ reported the estrogenic activity of genistein for human $\mathrm{ER} \alpha$ and $\mathrm{ER} \beta$, and the binding affinities of genistein for human $\operatorname{ER} \alpha$ and $\operatorname{ER} \beta$ were 4 and 87, respectively, whilst that for E2 was set to 100. These results indicate that phytoestrogens, such as genistein and daidzein, were the main substances contributing to the estrogenic activity of the diet.

Organochlorine pesticides, such as $\mathrm{HCB}, \beta$ BHC, $\gamma$-BHC, $t$-nonachlor, and/or endrin were detected in most fish diets. Among these organochlorine pesticides, $\beta$-BHC and endrin have been reported as estrogenic pesticides in the reporter gene assay, and the $20 \%$ relative effective concentration $\left(\mathrm{REC}_{20}\right)$ values of $\beta$-BHC and endrin for human $\mathrm{ER} \alpha$ were $3.5 \times 10^{-7}$ and $1.8 \times 10^{-6} \mathrm{M}$, respectively. ${ }^{21)}$ Considering the effective concentrations for human $\operatorname{ER} \alpha$, organochlorine pesticides such as $\beta$-BHC and endrin were not the main substances contributing to the estrogenic activity of the diet. However, it should be considered that the yeast two-hybrid system tested in this study basically shows lower responsiveness to estrogenic substances than that of the cultured animal cells. ${ }^{27)}$ Moreover, live foods, such as Artemia nauplii, can be a source of adventitious xenobiotics. The different geographic strains of Artemia cysts may contain various amounts and types of chlorinated and aromatic hydrocarbons and heavy metals. ${ }^{20)}$ Although adventitious contaminants such as organochlorine pesticides in unpurified commercial fish diets have not been evaluated in previous studies, our findings suggest that there are detectable levels of organochlorine pesticides in experimental fish diets.

To study the relationship between estrogenic activity and the phytoestrogen content of various diets from present and previous investigations, we evaluated the estrogenic activity of the feeding diet for experimental fish found by the yeast two-hybrid assay and the total amount of genistein and daidzein analysed by HPLC. In most diets (for $\mathrm{ER} \alpha$ and $\mathrm{ER} \beta$ ), a positive correlation was found between the E2 conversion from the phytoestrogen content (Fig. 3$\mathrm{Y}$ axis) and the estrogenic activity of $\mathrm{E} 2$ conversion by the yeast two-hybrid assay (Fig. 3-X axis). Therefore, it is strongly suggested that genistein and daidzein, which are phytoestrogens, largely contribute to the estrogenic activity of these diets for ER $\alpha$ and ER $\beta$. However, some diets, such as Nos. 2, 3 and 5 , were outside the regression curve in the relationship between the E2 conversion of the phytoestrogen content in the diet and the estrogenic activity for $\mathrm{E} 2$ conversion by the yeast two-hybrid assay. In the No. 5 diet, HCB, $\beta$-BHC, $\gamma$-BHC and endrin were detected at $8.15,14.18,10.13$ and $28.15 \mathrm{ng} / \mathrm{g}$, respectively. It is unclear whether there are combined effects of these substances with estrogenic activities from the fish diet. Furthermore, organochlorine pesticides, such as $\beta$-BHC and endrin 
have been reported as estrogenic substances, ${ }^{21)}$ although these organochlorine pesticides were not the main substances contributing to the estrogenic activity of the diet. Kojima et al. revealed anti-androgenic activity of pesticides such as vinclozolin and $p, p^{\prime}$-DDE. ${ }^{21)}$ The plants used as raw materials for the fish diet may contain other chemicals with antiestrogenic and (anti-)androgenic effects, although vinclozolin and $p, p^{\prime}$-DDE were not detected in the fish diets tested in this study. The effects of (anti)estrogenic and (anti-)androgenic substances in the fish diet should also be considered.

Our previous study reported that phytoestrogens (genistein, $58.5 \mu \mathrm{g} / \mathrm{g}$; daidzein, $37.3 \mu \mathrm{g} / \mathrm{g}$ ) were detected in a commercial fish diet, and this diet induced hepatic Vg synthesis in male medaka (Oryzias latipes). ${ }^{22)}$ Moreover, we reported that plasma Vg was detected in male goldfish fed $1.0 \%$ body weight of the diet containing phytoestrogens (genistein, $47.7 \mu \mathrm{g} / \mathrm{g}$; daidzein, $41.1 \mu \mathrm{g} / \mathrm{g}$ ) every two days for 31 days. ${ }^{28)}$ In the present study, genistein (concentrations ranging from 39.7 to $118.9 \mu \mathrm{g} / \mathrm{g}$ ) and daidzein (concentrations ranging from 28.7 to $81.3 \mu \mathrm{g} / \mathrm{g}$ ) were detected in all fish diets. These dietary concentrations of phytoestrogens with the exception of the No. 4 diet could be sufficiently high to cause the production of plasma Vg in male medaka and goldfish. Furthermore, our previous study ${ }^{18)}$ reported the effects of the xenoestrogen nonylphenol on the production of plasma $\mathrm{Vg}$ with the measurement of steroid hormones in goldfish fed on a diet with a high phytoestrogen content. The conclusion was that a large amount of phytoestrogens in the fish diet competed with nonylphenol in binding ER in the in vivo $\mathrm{Vg}$ production assay and may affect the estimation of the estrogenic activity of nonylphenol. These results strongly suggest that it is necessary to assess the estrogenic activity or contents of phytoestrogens such as genistein and daidzein in the fish diet when performing an in vivo screening assay for EDCs. Therefore, we recommend the use of a standardized, open-formula diet in which estrogenic substances have been reduced to levels that do not alter the results of studies which are influenced by exogenous estrogens.

Acknowledgements This work was supported by the fund for endocrine disrupters from the Ministry of the Environment, Japan.

\section{REFERENCES}

1) Colborn, T., Dumanoshi, D. and Myers, J. P. (1996) Our Stolen Future, Dutton, NY, U.S.A.

2) Colborn, T., vom Saal, F. S. and Soto, A. M. (1993) Developmental effects of endocrine-disrupting chemicals in wildlife and humans. Environ. Health Perspect., 101, 378-384.

3) Jobling, S., Sheahan, D., Osborne, J. A., Matthiessen, P. and Sumpter, J. P. (1996) Inhibition of testicular growth in rainbow trout (Oncorhynchus mykiss) exposed to estrogenic alkylphenolic chemicals. Environ. Toxicol. Chem., 15, 194-202.

4) OECD (1998) Report of the First Meeting of the OECD Endocrine Disrupter Testing and Assessment (EDTA) Working Group, Organization for Economic Cooperation and Development, Paris.

5) Soto, A. M., Sonnenschin, C., Chung, K. L., Fernandez, M. F., Olea, N. and Olea-Serrano, F. (1995) The E-SCREEN assay as a tool to identify estrogens: an update on estrogenic environmental pollutants. Environ. Health Perspect., 103, 113-122.

6) Routledge, E. J. and Sumpter, J. P. (1996) Estrogenic activity of surfactants and some of their degradation products assessed using a recombinant yeast screen. Environ. Toxicol. Chem., 15, 241-248.

7) Nishikawa, J., Saito, K., Goto, J., Dakeyama, F., Matsuo, M. and Nishihara, T. (1999) New screening methods for chemicals with hormonal activities using interaction of nuclear hormone receptor with coactivator. Toxicol. Applied Pharmacol., 154, 7683.

8) Shiraishi, F., Shiraishi, H., Nishikawa, J., Nishihara, T. and Morita, M. (2000) Development of a simple operational estrogenicity assay system using the yeast two-hybrid system. Jpn. J. Environ. Chem., 10, 57-64.

9) Yamasaki, K., Sawaki, M, and Takatsuki, M. (2000) Immature rat uterotrophic assay of bisphenol A. Environ. Health Perspect., 108, 1147-1150.

10) Sumpter, J. P. and Jobling, S. (1995) Vitellogenesis as a biomarker for estrogenic contamination of the aquatic environment. Environ. Health Perspect., 103, 173-178.

11) Hara, A. (1999) Vittelogenin in male as a biomarker for estrogenic contamination of the aquatic environment. Jpn. J. Environ. Toxicol., 2, 35-42.

12) Adams, N. R. and Sanders, M. R. (1988) Persistent infertility in ewes after prolonged exposure to oestradiol-17 $\beta$. J. Reprod. Fertil., 84, 373-378.

13) Obst, J. M. and Seamark, R. F. (1972) Plasma hormone levels during pregnancy and parturition in ewes grazing Yarloop clover patures. J. Reprod. Fertil., 29, 146-147.

14) Shutt, D. A. and Cox, R. I. (1972) Steroid and phyto- 
oestrogen binding to sheep uterine receptors in vitro. J. Endocrinol., 52, 299-310.

15) Thompson, M. A., Lasley, B. L., Rideout, B. A. and Kasman, L. H. (1984) Characterization of the estrogenic properties of a nonsteroidal estrogen, equol, extracted from urine of pregnant macaques. Biol. Reprod., 31, 705-713.

16) Adlercreutz, H., Hockerstedt, K., Bannwart, C., Bloigu, S., Hamalainen, E., Fotsis, T. and Ollus, A. (1987) Effect of dietary components, including lignans and phytoestrogens, on enterohepatic circulation and liver metabolism of estrogens and on sex hormone binding globulin (SHBG). J. Steroid. Biochem., 27, 1135-1144.

17) Owens, W., Ashby, J., Odum, J. and Onyon, L. (2003) The OECD program to validate the rat uterotrophic bioassay. Phase 2: dietary phytoestrogen analyses. Environ. Health Perspect., 111, 1559-1567.

18) Ishibashi, H., Tachibana, K., Tsuchimoto, M., Soyano, K., Tatarazako, N., Matsumura, N., Tomiyasu, Y., Tominaga, N. and Arizono, K. (2004) Effects of nonylphenol and phytoestrogen-enriched diet on production of plasma vitellogenin, steroid hormone, hepatic cytochrome P450 1A and glutathione-S-transferase values in goldfish (Carassius auratus). Comp. Med., 54, 54-62.

19) Nishihara, T., Nishikawa, J., Kanayama, T., Dakeyama, F., Saito, K., Imagawa, M., Takatori, S., Kitagawa, Y., Hori, S. and Utsumi, H. (2000) Estrogenic activities of 517 chemicals by yeast two-hybrid assay. J. Health Sci., 46, 282-298.

20) DeKoven, D. L., Nunez, J. M., Lester, S. M., Conklin, D. E., Marty, G. D., Parker, L. M. and Hinton, D. E. (1992) A purified diet for medaka (Oryzias latipes): refining a fish model for toxicological research. Lab. Anim. Sci., 42, 180-189.

21) Kojima, H., Katsura, E., Takeuchi, S., Niiyama, K. and Kobayashi, K. (2004) Screening for estrogen and androgen receptor activities in 200 pesticides by in vitro reporter gene assays using Chinese hamster ovary cells. Environ. Health Perspect., 112, 524531.

22) Inudo, M., Ishibashi, H., Matsumura, N., Matsuoka, M., Mori, T., Taniyama, S., Kadokami, K., Koga, M., Shinohara, R., Hutchinson, T. H., Iguchi, T. and Arizono, K. (2004) Effect of estrogenic activity, and phytoestrogen and organochlorine pesticide contents in an experimental fish diet on reproduction and hepatic vitellogenin production in medaka (Oryzias latipes). Comp. Med., 54, 673-680.

23) Miyahara, M., Ishibashi, H., Inudo, M., Nishijima, H., Iguchi, T., Guillette, L. J., Jr. and Arizono, K. (2003) Estrogenic activity of a diet to estrogen receptors- $\alpha$ and $-\beta$ in an experimental animal. J. Health Sci., 49, 1-11.

24) Court, M. H. and Freeman, L. M. (2002) Identification and concentration of soy isoflavones in commercial cat foods. Am. J. Vet. Res., 63, 181-185.

25) Kudou, S., Tsuizaki, I., Uchida, T. and Okubo, K. (1991) Purification and some properties of soybean saponin hydrolase from Aspergillus oryzae KO-2. Agric. Biol. Chem., 55, 31-36.

26) Kuiper, G. G. J. M., Lemmen, J. G., Carlsson, B., Corton, J. C., Safe, S. H., van der Saag, P. T., van der Burg, B. and Gustafsson, J. A. (1998) Interaction of estrogenic chemicals and phytoestrogens with estrogen receptor $\beta$. Endocrinology, 139, 4252-4263.

27) Jung, J., Ishida, K. and Nishihara, T. (2004) Antiestrogenic activity of fifty chemicals evaluated by in vitro assays. Life. Sci., 74, 3065-3074.

28) Ishibashi, H., Kobayashi, M., Koshiishi, T., Moriwaki, T., Tachibana, K., Tsuchimoto, M., Soyano, K., Iguchi, T., Mori, C. and Arizono, K. (2002) Induction of plasma vitellogenin synthesis by the commercial fish diets in male goldfish (Carassius auratus) and dietary phytoestrogens. $J$. Health Sci., 48, 427-434. 